\title{
EFEKTIFITAS KOMUNIKASI DOKTER TERHADAP KEPUASAN PASIEN RAWAT JALAN DI RSU IMELDA PEKERJA INDONESIA KOTA MEDAN
}

\author{
Erlina Rambe*, Tri Niswati Utami, Jamaluddin \\ S2 IImu Kesehatan Masyarakat, Institut Kesehatan Helvetia Medan \\ Email : erlinarambe95@gmail.com
}

\begin{abstract}
ABSTRAK
Komunikasi antara pasien dan dokter melibatkan interaksi yang mendalam diantara kedua belah pihak. Penelitian ini bertujuan untuk menganalisis Efektifitas Komunikasi Dokter terhadap kepuasan pasien rawat jalan di RSU. Imelda Pekerja Indonesia Medan. Penelitian ini merupakan survei analitik dengan rancangan cross sectional study yang dilakukan di RSU. Imelda Pekerja Indonesia Medan Tahun pada bulan Mei hingga Juni Tahun 2020. Populasi dalam penelitian ini adalah Populasi dalam penelitian ini adalah seluruh pasien yang berkunjung sebanyak 76 orang. Pengambilan sampel dilakukan secara total sampling. Data penelitian di analisis dengan rumus Chi Square dan regresi logistik. Berdasarkan hasil penelitian diketahui bahwa ada pengaruh keterbukaan (openess) dokter terhadap kepuasan pasien rawat jalan di RSU. Imelda Pekerja Indonesia Medan, ada pengaruh Emphaty (empati) dokter terhadap kepuasan pasien rawat jalan di RSU. Imelda Pekerja Indonesia Medan, ada pengaruh sikap (supportiveness) dokter terhadap kepuasan pasien rawat jalan di RSU. Imelda Pekerja Indonesia Medan, ada pengaruh kesetaraan (equality) dokter terhadap kepuasan pasien rawat jalan di RSU. Imelda Pekerja Indonesia Medan. Penelitian ini menyarankan agar dokter dapat terus meningkatkan kecakapan atau kemampuan berkomunikasi sehingga mampu membuat pasien terbuka, memiliki sikap mendukung, positif dan kesetaraan agar dokter dapat informasi yang diperlukan dan memberikan penanganan yang tepat kepada pasien dan pasien menjadi sembuh.
\end{abstract}

Kata Kunci: Keterbukaan, Empati, Sikap, Kesetaraan, Kepuasan Pasien

\begin{abstract}
Communication between patient and doctor involves deep interaction between the two parties. This study aims to analyze the effectiveness of doctor communication on the satisfaction of outpatients at the General Hospital. Imelda Medan Indonesian Workers. This study is an analytic survey with a cross sectional study design conducted at the General Hospital. Imelda Medan Indonesian Workers Years from May to June 2020. The population in this study is the population in this study were all patients who visited as many as 76 people. Sampling was done in total sampling. Research data were analyzed using the Chi Square formula and logistic regression. Based on the results of the study note that there is an influence of openness (openess) of doctors on the satisfaction of outpatients in public hospitals. Imelda Medan Indonesian Workers, there was the influence of Emphaty (empathy) doctors on the satisfaction of outpatients in the General Hospital. Imelda Medan Indonesian Workers, there is an influence of the attitude (supportiveness) of doctors on the satisfaction of outpatients in the General Hospital. Imelda Medan Indonesian Workers, there is an effect of the equality of doctors on the satisfaction of outpatients in the General Hospital. Imelda Medan Indonesian Workers. This study suggests that doctors can continue to improve their communication skills or abilities so as to make patients open, have a supportive, positive attitude and equality so that doctors can get the information needed and provide appropriate treatment to patients and patients recover.
\end{abstract}

\section{Keywords: Openness, Empathy, Attitude, Equality, Patient Satisfaction}

\section{PENDAHULUAN}

Salah satu langkah memperbaiki mutu pelayanan di rumah sakit adalah melalui komunikasi dokter di rumah sakit, dalam profesi dunia kedokteran, komunikasi antara dokter dengan pasien merupakan sebuah kompetensi yang harus dikuasai oleh seorang dokter, kompetensi inilah yang menentukan keberhasilan seorang dokter dalam membantu masalah kesehatan pasien
Interaksi antara dokter dan pasien tidak hanya meliputi aspek kebahasaan, tetapi juga meliputi pula hubungan sosial di antara keduanya. Dalam hal ini, interaksi dokter dan pasien merupakan komunikasi yang melibatkan dua orang dengan peran sosial yang berbeda.

Perbedaan tersebut menjadikan hubungan keduanya mengarah pada hubungan asimetris, perbedaan peran sosial di antara kedua belah pihak, tentu saja dapat memengaruhi pola 
interaksi keduanya dalam proses perawatan. dengan kata lain, interaksi yang asimetris tersebut turut memengaruhi diagnosis dan pengobatan yang tepat untuk pasien. ${ }^{1}$

Hubungan asimetris dalam interaksi dokter dan pasien menyebabkan seorang pasien merasa canggung saat berkomunikasi dengan dokter. Bahkan beberapa pasien merasa tidak memiliki keberanian untuk bertanya tentang penyakitnya setelah menjelaskan gejala yang dialaminya. Sementara beberapa pasien lebih suka mengikuti alur percakapan dokter dan hanya memberikan jawaban-jawaban singkat terhadap pertanyaan dokter. ${ }^{2}$

Seorang dokter harus benar-benar memahami betul apa yang menjadi keluhan dari pasien tersebut, oleh sebab itu komunikasi antara dokter dengan pasien sangat diperlukan. Biasanya komunikasi yang terjadi antara dokter dengan pasien terbilang singkat, dokter hanya menanyakan seperlunya saja, tidak ada waktu yang cukup untuk mereka saling berbincang-bincang, padahal perbincangan diantara keduanya sangat bermanfaat bagi dokter untuk dapat memahami lebih dalam apa yang menjadi keluhan atau penyakit yang dialami oleh pasien.

Komunikasi antara pasien dan dokter melibatkan interaksi yang mendalam diantara kedua belah pihak. Proses perawatan dilakukan dokter terhadap pasiennya berdasarkan hubungan saling percaya satu sama lain. Dii satu sisi, seorang dokter diharapkan terbuka kepada pasiennya mengenai gejala, penyakit, dan diagnosisnya. Sementara di sisi lain, seorang pasien diharapkan mampu berterus terang tentang gejala penyakit yang dirasakannya kepada dokter. Karena kualitas komunikasi dokter dan pasien yang kurang baik, dokter tidak dapat menyelesaikan semua masalah dalam penyediaan informasi yang terkait dengan proses perawatan. Jika hal ini terjadi, maka dokter tidak mampu memotivasi pasien untuk sembuh. Komunikasi dokter dan pasien pada dasarnya merupakan interaksi antara dua pihak (pengirim pesan dan penerima pesan) yang dilakukan melalui suatu proses, sehingga terjadi perpindahan pesan secara sempurna.

Komunikasi kesehatan antara dokter dan pasien adalah proses komunikasi yang melibatkan pesan kesehatan, unsur-unsur atau peserta komunikasi. Komunikasi yang dibangun dengan baik antara dokter dan pasien merupakan salah satu kunci keberhasilan dokter dalam memberikan upaya pelayanan medis.Komunikasi dokter dan pasien sering berlangsung dalam situasi yang tingkat stresnya tinggi dan harus dilakukan segera sehingga sering meningkatkan terjadinya miskomunikasi antara dokter dan pasien. $^{3}$

Salah satu Rumah Sakit yang mengalami penurunan jumlah pengunjung adalah Rumah Sakit Imelda Pekerja Indonesia, Rumah Sakit yang terletak di lokasi strategis di kota Medan telah memiliki fasilitas penunjang pelayanan kesehatan yang lengkap dan didukung oleh Sumber Daya Manusia (SDM) yang berkualitas. Akan tetapi berdasarkan data kunjungan, khususnya data kunjungan pasien BPJS pada tahun 2018 dan 2020 mengalami penurunan. Untuk lebih jelasnya dapat dilihat pada tabel berikut.

Tabel 1. Angka Kunjungan Pasien BPJS Rawat Jalan Rumah Sakit. Imelda Pekerja Indonesia Medan Tahun 2018 dan Tahun 2020

\begin{tabular}{lllc}
\hline No & Bulan & \multicolumn{2}{c}{ Jumlah Kunjungan } \\
\cline { 3 - 4 } & & Tahun 2018 & Tahun 2020 \\
\hline 1 & Januari & 4.525 & 2.414 \\
2 & Februari & 4.041 & 1.926 \\
3 & Maret & 4.449 & 2.179 \\
4 & April & 4.055 & 2.024 \\
5 & Mei & 4.096 & 2.159 \\
6 & Juni & 2.978 & 1.609 \\
7 & Juli & 4.303 & 2.020 \\
8 & Agustus & 4.140 & 1.880 \\
9 & September & 3.092 & 1.999 \\
10 & Oktober & 2.847 & 2.056 \\
11 & November & 2.470 & 1.556 \\
12 & Desember & 2.371 & 1.646 \\
\hline & Total & $\mathbf{4 3 . 0 6 4}$ & $\mathbf{2 3 . 4 6 8}$ \\
\hline
\end{tabular}


Berdasarkan tabel di atas diketahui bahwa jumlah kunjungan mulai dari bulan September hingga bulan Desember tahun 2018 sangat drastis menurun dan dari tabel tersebut juga terlihat jumlah kunjungan tahun 2020 apabila dibandingan dengan jumlah kunjungan tahun 2018 sangat menurun yaitu selisihnya mencapai 19. 596. Oleh sebab itu pada tanggal 21 April tahun 2020, peneliti melakukan survey awal di Rumah Sakit Umum Imelda Pekerja Indonesia untuk mengetahui apa penyebab menurunnya jumlah kunjungan di Rumah Sakit Umum Imelda Pekerja Indonesia tersebut.

Berdasarkan hasil survey awal yang dilakukan dengan memberikan kuesioner kepada 10 orang pasien, diketahui bahwa sebanyak 7 orang pasien yang tidak puas terhadap pelayanan di rumah sakit tersebut, sedangkan 4 oranglainnya mengaku puas. Kemudian peneliti mewawancarai ke 10 orang tersebut dan memeroleh jawaban bervariasi, dimana 3 orang mengatakan karena pelayanan kurang nyaman seperti kurang cepatnya petugas pelayanan menanggapi keluhan dari pasien serta pelayanan administrasi yang kurang cepat dan 7 orang lainnya menyatakan bahwa dokternya kurang ramah dan kurang berkomunikasi dengan pasien, sehingga pasien sulit memahami apa yang disampaikan oleh dokter tentang penyakit yang di deritanya, selain itu mereka juga menyatakan bahwa dokternya sering terburu-buru sehingga kurang puas dalam melakukan konseling. Berdasarkan hal tersebut, sebanyak 7 orang pasien menyatakan tidak akan datang lagi berobat ke Rumah Sakit dan tidak akan merekomendasikan Rumah Sakit tersebut kepada pihak lain.

Berdasarkan hasil observasi terhadap 10 orang dokter yang sedang memberikan pelayanan kepada pasien. Diketahui bahwa, semua dokter menyatakan bahwa mereka selalu ramah terhadap pasien, memberikan waktu pada pasien untuk menyampaikan keluhannya, tidak pernah terburu-buru dalam menyampaikan informasi tentang kesehatan pasien serta mendengarkan keluhan pasien. Dokter juga selalu menjaga rahasia hasil diagnosis ataupun privasi pasien lainnya. Tidak setiap pasien berkenan penyakitnya diketahui oleh orang lain. Dokter juga menyatakan bahwa salah satu bentuk kerendahan hati itu ialah komitmen untuk mengobati semua pasien tanpa melihat status sosial dan level ekonomi mereka. Kewajiban dokter di hadapan pasien sama, baik mereka yang kaya maupun miskin, tetap harus diobati.Meskipun demikian, masih banyak pasien yang tidak puas dengan pelayanan dokter

Uraian tersebut, menunjukkan bahwa pasien masih mengalami ketidakpuasan atas pelayanan yang diberikan oleh dokter. Keluhan maupun pengalaman yang dirasakan pasien setelah menerima pelayanan merupakan suatu indikator kualitas pelayanan kesehatan yang perlu diperhatikan, sehingga pasien selalu puas terhadap sebuah rumah sakit.

Berdasarkan latar belakang diatas maka tujuan penelitian ini adalah untuk menganalisis Efektifitas Komunikasi Dokter terhadap kepuasan pasien rawat jalan di RSU. Imelda Pekerja Indonesia Medan Tahun 2020.

\section{BAHAN DAN METODE}

Jenis penelitian ini merupakan survei analitik dengan rancangan cross sectional study. Penelitian dilakukan di RSU. Imelda Pekerja Indonesia Medan. Populasi dalam penelitian ini adalah seluruh pasien yang berkunjung di RSU. Imelda Pekerja Indonesia Medan pada bulan Juni tahun 2020 yaitu sebanyak 76 orang. Menurunnya jumlah kunjungan tersebut erat kaitannya dengan Pandemi Covid 19, sehingga tidak banyak pasien yang berkunjung ke rumah sakit. Sampel penelitian ada sebanyak 76 orang. Untuk menganalisis data digunakan uji chisquare dan regresi logistik.

\section{HASIL}

\section{Analisis Data Univariat}

Berdasarkan data yang diperoleh dari hasil penelitian dengan 76 responden dapat dilihat dalam tabel distribusi frekuensi sebagai berikut.

Tabel 2. Distribusi Responden di Ruang Rawat Jalan RSU. Imelda Pekerja Indonesia Medan

\begin{tabular}{lrr}
\hline Kelompok Umur & $\mathbf{n}$ & \% \\
\hline 21-25 Tahun & 7 & 9,21 \\
26-35 Tahun & 17 & 22,36 \\
36-45 Tahun & 27 & 35,53 \\
46-55 Tahun & 20 & 26,32 \\
56-65 Tahun & 5 & 6,58 \\
\hline Tingkat Pendidikan & $\mathbf{n}$ & $\%$ \\
\hline SMP & 15 & 19,74
\end{tabular}




\begin{tabular}{lrr} 
SMA & 37 & 48,68 \\
PT & 24 & 31,58 \\
\hline Pekerjaan & $\mathbf{n}$ & $\%$ \\
\hline Petani & 4 & 5,27 \\
Wiraswasta & 26 & 34,21 \\
PNS & 21 & 27,63 \\
Lain-lainnya & 25 & 32,89 \\
\hline Jumlah & $\mathbf{7 6}$ & $\mathbf{1 0 0}$ \\
\hline
\end{tabular}

Berdasarkan tabel 2 di atas, diketahui bahwa dari 76 responden, sebagian besar responden berumur 36-45 tahun yaitu sebanyak $27(35,53 \%)$ responden, sedangkan responden lainnya berumur 21-25 tahun yaitu sebanyak 5 $(9,21 \%)$ responden, umur 26-35 tahun sebanyak $17(22,36 \%)$, umur 46-55 tahun sebanyak 20 (26,32\%), umur 56-65 tahun 5 $(6,58 \%)$ responden.

Dari 76 responden diketahui bahwa sebagian besar responden merupakan tamatan SMA yaitu sebanyak $37(48,68 \%)$ responden, tamatan SMP sebanyak $15(19,74 \%)$ responden dan tamatan PT ada sebanyak 24 (31,58\%) responden. Dari 76 responden diketahui bahwa sebagian besar responden memiliki pekerjaan wiraswasta yaitu sebanyak 26 $(34,21 \%)$ responden, responden lainnya memiliki pekerjaan petani yaitu sebanyak 4 $(5,27 \%)$ responden, memiliki pekerjaan PNS yaitu sebanyak $21(27,63 \%)$ responden, dan yang memiliki pekerjaan lain-lainnya yaitu sebanyak $25(32,89 \%)$ responden.

\section{Analisis Data Bivariat}

Untuk mengetahui Efektifitas Komunikasi Dokter terhadap kepuasan pasien rawat jalan di RSU. Imelda Pekerja Indonesia Medan Tahun 2020, dapat dilihat pada tabel dibawah ini:

Tabel 3. Analisis Efektifitas Komunikasi Dokter terhadap kepuasan pasien rawat jalan di RSU. Imelda Pekerja Indonesia Medan

\begin{tabular}{|c|c|c|c|c|c|c|c|c|c|}
\hline & \multicolumn{6}{|c|}{ Kepuasan } & \multirow{3}{*}{ OR } & \multirow{3}{*}{$95 \% \mathrm{Cl}$} & \multirow{3}{*}{$\begin{array}{c}P \\
\text { value }\end{array}$} \\
\hline & \multicolumn{2}{|c|}{ Tidak Puas } & \multicolumn{2}{|c|}{ Puas } & \multicolumn{2}{|c|}{ Total } & & & \\
\hline & $\mathbf{n}$ & $\%$ & $\mathbf{n}$ & $\%$ & $\mathbf{N}$ & $\%$ & & & \\
\hline \multicolumn{10}{|l|}{ Keterbukaan } \\
\hline Tidak Terbuka & 19 & 65,52 & 10 & 34,48 & 29 & 100 & \multirow{2}{*}{8,022} & \multirow{2}{*}{$2,792-23,053$} & \multirow{2}{*}{0,000} \\
\hline Terbuka & 9 & 19,15 & 38 & 80,85 & 47 & 100 & & & \\
\hline \multicolumn{10}{|l|}{ Empati } \\
\hline Ya & 20 & 71,43 & 8 & 28,57 & 28 & 100 & \multirow[t]{2}{*}{12,500} & \multirow[t]{2}{*}{$4,089-38,209$} & \multirow[t]{2}{*}{0,000} \\
\hline Tidak & 8 & 16,67 & 40 & 83,33 & 48 & 100 & & & \\
\hline \multicolumn{10}{|l|}{ Sikap } \\
\hline Negatif & 20 & 66,67 & 10 & 33,33 & 30 & 100 & \multirow[t]{2}{*}{9,500} & \multirow[t]{2}{*}{$3,240-27,859$} & \multirow[t]{2}{*}{0,000} \\
\hline Positif & 8 & 17,39 & 38 & 82,61 & 46 & 100 & & & \\
\hline \multicolumn{10}{|l|}{ Kesetaraan } \\
\hline Tidak Setara & 33 & 86,84 & 5 & 13,16 & 38 & 100 & \multirow[t]{2}{*}{9,148} & \multirow[t]{2}{*}{$3,124-26,788$} & \multirow[t]{2}{*}{0,000} \\
\hline Setara & 6 & 23,88 & 20 & 76,92 & 26 & 100 & & & \\
\hline Total & 28 & 36,84 & 48 & 63,16 & 76 & 100 & & & \\
\hline
\end{tabular}

Berdasarkan tabel 3 diketahui bahwa dari 76 responden yang diteliti, sebagian besar responden mengatakan bahwa dokter terbuka sebanyak $47(61,84 \%)$ responden. Dari 47 $(61,84 \%)$ responden tersebut, ada sebanyak 9 $(19,15 \%)$ responden mengatakan bahwa dokter terbuka dan tidak puas, sebanyak $38(80,85 \%)$ mengatakan bahwa dokter terbuka dan puas. Berdasarkan hasil perhitungan di atas diketahui bahwa hasil uji statistik diperoleh nilai pada baris OR yaitu 8,022 (95\% $\mathrm{Cl}: 2,792-23,053)$ yang artinya responden yang mengatakan bahwa dokter terbuka kemungkinan 13,378 kali lebih puas daripada responden yang mengatakan bahwa dokter tidak terbuka. Nilai $p$ significancy yaitu $0,000<0,05$. Sehingga dapat disimpulkan bahwa ada pengaruh komunikasi dokter pada aspek keterbukaan (openess) terhadap Kepuasan pasien rawat jalan di RSU. Imelda Pekerja Indonesia Medan Tahun 2020. 
Berdasarkan tabel 3 diketahui bahwa dari 76 responden yang diteliti, sebagian besar responden mengatakan bahwa dokter empati sebanyak $48(6316 \%)$ responden. Dari 48 $(6316 \%)$ responden tersebut, ada sebanyak 8 $(16,67 \%)$ responden mengatakan bahwa dokter empati dan tidak puas, sebanyak 40 (83,33\%) mengatakan bahwa dokter empati dan puas. Berdasarkan hasil perhitungan di atas diketahui bahwa hasil uji statistik diperoleh nilai pada baris OR yaitu 12,500 (95\% $\mathrm{Cl}$ : 4,089-38,209) yang artinya responden yang mengatakan bahwa dokter empati kemungkinan 12,500 kali puas daripada responden yang mengatakan bahwa dokter tidak empati. Nilai $p$ significancy yaitu $0,000<0,05$. Sehingga dapat disimpulkan bahwa ada pengaruh komunikasi dokter pada aspek empati (emphaty) terhadap kepuasan pasien rawat jalan di RSU. Imelda Pekerja Indonesia Medan Tahun 2020.

Berdasarkan tabel 2 diketahui bahwa dari 76 responden yang diteliti, sebagian besar responden mengatakan bahwa dokter menunjukkan sikap positif sebanyak 46 $(60,53 \%)$ responden. Dari $46 \quad(60,53 \%)$ responden tersebut, ada sebanyak $8(17,39 \%)$ responden mengatakan bahwa dokter menunjukkan sikap positif dan tidak puas, sebanyak 38 (80,85\%) mengatakan bahwa dokter menunjukkan sikap positif dan puas. Berdasarkan hasil perhitungan di atas diketahui bahwa hasil uji statistik diperoleh nilai pada baris OR yaitu 9,500 (95\%Cl: 2,240-27,859) yang artinya responden yang mengatakan bahwa dokter menunjukkan sikap positif kemungkinan 13,378 kali lebih puas daripada responden yang mengatakan bahwa dokter menunjukkan sikap negatif terbuka. Nilai $p$ significancy yaitu $0,000<0,05$. Sehingga dapat disimpulkan bahwa ada pengaruh komunikasi dokter pada aspek sikap (supportiveness) terhadap kepuasan pasien rawat jalan di RSU. Imelda Pekerja Indonesia Medan Tahun 2020.

Berdasarkan tabel 2 diketahui bahwa dari 76 responden yang diteliti, sebagian besar responden mengatakan bahwa dokter terbuka sebanyak $48(6316 \%)$ responden. Dari 48 $(6316 \%)$ responden tersebut, ada sebanyak 9 $(18,75 \%)$ responden mengatakan bahwa dokter menunjukkan kesetaraan (equality) dan tidak puas, sebanyak 39 (81,25\%) mengatakan bahwa dokter menunjukkan kesetaraan (equality) dan puas. Berdasarkan hasil perhitungan di atas diketahui bahwa hasil uji statistik diperoleh nilai pada baris OR yaitu 9,148 (95\%Cl: 3,124-26,788) yang artinya responden yang mengatakan bahwa dokter menunjukkan kesetaraan (equality) kemungkinan 9,148 kali lebih puas daripada responden yang mengatakan bahwa dokter tidak menunjukkan kesetaraan. Nilai $p$ significancy yaitu $0,000<0,05$. Sehingga dapat disimpulkan bahwa ada pengaruh komunikasi dokter pada aspek kesetaraan (equality) terhadap kepuasan pasien rawat jalan di RSU. Imelda Pekerja Indonesia Medan Tahun

2020.

Tabel 4 Hasil Tahapan Akhir Analisis Regresi Logistik

\begin{tabular}{lcccc}
\hline Variabel & B & p value & Exp(B)OR & 95\%Cl for Exp(B) \\
\hline Keterbukaan & 3,598 & 0,003 & 36,512 & $3,404-391,605$ \\
Empati & 2,901 & 0,008 & 18,193 & $2,157-153,414$ \\
Sikap & 3,239 & 0,001 & 25,511 & $3,595-181,054$ \\
Kesetaraan & 4,234 & 0,001 & 68,985 & $5,429-876,548$ \\
\hline
\end{tabular}

Berdasarkan tabel 4 di atas dapat dilihat bahwa analisis regresi logistik menghasilkan 1 (satu) variabel yang dominan berpengaruh terhadap kepuasan pasien rawat jalan di RSU Imelda Pekerja Indonesia Medan Tahun 2020 dengan $\mathrm{p}$ value $<0,05$, yaitu variabel kesetaraan dengan signifikan 0,001 ( $\mathrm{p}$ value $<0,05), \mathrm{OR}=68,985(95 \% \mathrm{Cl}=5,429-876,548)$ artinya responden yang mengatakan bahwa dokter menunjukkan kesetaraan mempunyai peluang 68,985 kali lebih puas dibandingkan dengan responden yang mengatakan bahwa dokter tidak menunjukkan kesetaraan dengan nilai koefisien B yaitu 4,234 bernilai positif, jadi semakin banyak responden yang mengatakan bahwa dokter menunjukkan kesetaraan maka semakin banyak pasien yang puas di RSU Imelda Pekerja Indonesia Medan Tahun 2020.

\section{PEMBAHASAN}

Sikap profesional seorang dokter ditunjukkan ketika dokter berhadapan dengan tugasnya, yang berarti mampu menyelesaikan tugas-tugasnya sesuai peran dan fungsinya; mampu mengatur diri sendiri seperti ketepatan waktu, pembagian tugas profesi dengan tugastugas pribadi yang lain dan mampu 
menghadapi berbagai macam tipe pasien serta mampu bekerja sama dengan profesi kesehatan yang lain. $\mathrm{Di}$ dalam proses komunikasi dokter-pasien, sikap profesional ini penting untuk membangun rasa nyaman, aman, dan percaya pasien pada dokter, yang merupakan landasan bagi berlangsungnya komunikasi secara terbuka.

Kualitas keterbukaan mengacu pada sedikitnya tiga aspek dari komunikasi interpersonal. Pertama, komunikator interpersonal yang efektif harus terbuka kepada orang yang diajaknya berinteraksi. Ini tidaklah berarti bahwa orang harus dengan segera membukakan semua riwayat hidupnya. Memang ini menarik, tapi biasanya tidak membantu komunikasi. Sebaliknya, harus ada kesediaan untuk membuka diri mengungkapkan informasi yang biasanya disembunyikan, asalkan pengungkapan diri ini patut. Aspek keterbukaan yang kedua mengacu kepada kesediaan komunikator untuk bereaksi secara jujur terhadap stimulus yang datang. Orang yang diam, tidak kritis, dan tidak tanggap pada umumnya merupakan peserta percakapan yang menjemukan. Kita ingin orang bereaksi secara terbuka terhadap apa yang kita ucapkan. Dan kita berhak mengharapkan hal ini. Tidak ada yang lebih buruk daripada ketidakacuhan, bahkan tidak sependapat jauh lebih menyenangkan. Kita memperlihatkan keterbukaan dengan cara bereaksi secara spontan terhadap orang lain.

Komunikasi yang terbuka setiap saat ketika terjadi hal yang tidak diinginkan, pasien dan keluarganya harus diberikan informasi mengenai apa yang telah terjadi dengan jujur dan terbuka sepanjang waktu. Informasi mengenai proses yang sedang berlangsung sebaiknya juga diberikan.

Seseorang ingin orang bereaksi secara terbuka terhadap apa yang diucapkan dan berhak mengharapkan hal ini. Tidak ada yang lebih buruk daripada ketidakacuhan, bahkan tidak sependapat jauh lebih menyenangkan. Seseorang memperlihatkan keterbukaan dengan cara bereaksi secara spontan terhadap orang lain.

Pada saat penelitian, peneliti mengamati bahwa beberapa dokter menyilakan masuk dan mengucapkan salam, memanggil/menyapa pasien dengan namanya, menciptakan suasana yang nyaman (isyarat bahwa punya cukup waktu, menganggap penting informasi yang akan diberikan, menghindari tampak lelah)., memperkenalkan diri, menatap mata pasien secara profesional yang lebih terkait dengan makna menunjukkan perhatian dan kesungguhan mendengarkan., memperhatikan keluhan yang disampaikan tanpa melakukan interupsi yang tidak perlu. Apabila pasien marah, menangis, takut, dan sebagainya maka dokter tetap menunjukkan raut wajah dan sikap yang tenang, melibatkan pasien dalam rencana tindakan medis selanjutnya atau pengambilan keputusan, memeriksa ulang segala sesuatu yang belum jelas bagi kedua belah pihak.

Empati adalah sebagai kemampuan seseorang untuk 'mengetahui' apa yang sedang dialami orang lain pada suatu saat tertentu, dari sudut pandang orang lain itu, melalui kacamata orang lain itu. Bersimpati, di pihak lain adalah merasakan bagi orang lain atau merasa ikut bersedih. Sedangkan berempati adalah merasakan sesuatu seperti orang yang mengalaminya, berada di kapal yang sama dan merasakan perasaan yang sama dengan cara yang sama. Orang yang empatik mampu memahami motivasi dan pengalaman orang lain, perasaan dan sikap mereka, serta harapan dan keinginan mereka untuk masa mendatang.

Di dalam komunikasi dokter-pasien, ada dua sesi yang penting, yaitu sesi pengumpulan informasi yang di dalamnya terdapat proses anamnesis, dan sesi penyampaian informasi. Tanpa penggalian informasi yang akurat, dokter dapat terjerumus ke dalam sesi penyampaian informasi (termasuk nasihat, sugesti atau motivasi dan konseling) secara prematur. Akibatnya pasien tidak melakukan sesuai anjuran dokter.

Aspek emphaty (empati) adalah kemudahan dalam melakukan hubungan komunikasi yang baik, perhatian pribadi dan memahami kebutuhan pasien sebagai pelanggan dan bertindak demi kepentingan pasien. Dokter diharapkan bisa memahami kesulitan-kesulitan pribadi masing-masing pasien dan membantu mereka keluar dari kesulitannya. Pasien akan merasa diperhatikan oleh Dokter jika apa yang dibutuhkan dan dikeluhkannya ditanggapi secara baik oleh pihak Dokter, dan sikap yang tulus dan berifat individual atau pribadi yang diberikan Dokter kepada pasien seperti kemudahan untuk menghubungi Dokter, kemampuan Dokter untuk berkomunikasi dengan pasien dan keluarga pasien. Semakin baik persepsi Dokter terhadap kepedulian (empathy) maka kepuasan pasien akan semakin tinggi. Dan jika persepsi pasien terhadap kepedulian (empathy) buruk, maka kepuasan pasien akan semakin rendah. .

Gronroos, Sharma dan Patterson (2000) menegaskan bahwa kualitas fungsional dihubungkan dengan emphaty (empati) penyedia jasa dan penerima jasa dan dinilai dalam hal yang sangat subyektif. Hal ini dilihat sebagai suatu hal yang kritis untuk persepsi pasien dari kualitas pelayanan secara 
keseluruhan. Khususnya ketika banyak pemberi jasa sulit untuk membedakan dirinya sendiri hanya pada pelayanan inti kemudian menjadi komoditas saat persaingan meningkat dan industri menjadi dewasa, maka dimensi kualitas fungsional menjadi semakin penting sebagai alat menciptakan keuntungan kompetitif yang dapat didukung. Maka dapat disimpulkan bahwa pelayanan merupakan suatu bentuk sistem, prosedur atau metode tertentu diberikan kepada orang lain, dengan harapan atau keinginan pelanggan dengan tingkat persepsi mereka. Faktor yang menyebabkan timbulnya pelayanan yaitu: adanya rasa cinta dan kasih sayang, adanya keyakinan bahwa berbuat baik kepada orang lain. ${ }^{4}$

Kotler (2005) menyatakan bahwa empati Dokter yang dimaksud adalah kesediaan untuk lebih peduli memberikan perhatian kepada pasien. Perhatian yang diberikan Dokter dapat dilakukan dengan memperlihatkan sikap caring terhadap pasien. Dalam memberikan asuhan keDokteran kepada pasien, Dokter menggunakan kata-kata yang lemah lembut, sentuhan, memberikan harapan, selalu berada disamping pasien saat dibutuhkan sehingga pasien merasa puas terhadap perhatian yang diberikan Dokter. $^{5}$

Pasien yang merasa puas akan kembali lagi memanfaatkan pelayanan rumah sakit jika mereka membutuhkannya lagi dan berpendapat bahwa Dokter memiliki kontribusi yang unik terhadap kepuasan pasien dan keluarganya. Pelayanan dan perilaku Dokter merupakan faktor yang sangat berhubungan terhadap kepuasan pasien. Peningkatan prioritas kepuasan pasien adalah memperbaiki kualitas pelayanan dengan mendistribusikan pelayanan yang adil, ramah dan sopan.

Menurut asumsi peneliti, empati dalam suatu pelayanan adalah adanya sutau perhatian, keseriusan, pengertian dan keterlibatan pihak-pihak yang berkepentingan dengan pelayanan untuk mengembangkan dan melakukan aktifitas pelayanan sesuatu dengan tingkat pengertian dan pemahaman dari masing-masing pihak tersebut. Pihak yang memberikan pelayanan harus memiliki empati memahami masalah dari pihak yang ingin dilayani. Pihak yang dilayani seyogyanya memahami keterbatasan dan kemampuan orang yang melayani. Sehinga keterpaduan antara pihak yang melayani dan mendapat pelayanan memiliki perasaan yang sama. Berarti dalam suatu organisasi kerja menjadi sangat penting dalam memberikan suatu kualitas pelayanan sesuai prestasi kerja yang ditunjukkan oleh seorang Dokter. Empati tersebut mempunyai inti yaitu mampu memahami orang yang dilayani dengan penuh perhatian, keseriusan, simpatik, pengertian dann adanya keterlibatan dalam berbagai permasalahan yang dihadapi orang yang dilayani.

Motivasi dari tim medis bisa menurunkan kecemasan dengan memberikan dukungandukungan emosional berupa kesabaran, perhatian, motivasi supaya pasien akan sembuh lebih cepat. Hubungan interpersonal yang efektif adalah hubungan dimana terdapat sikap mendukung (supportiveness). Komunikasi yang terbuka dan empati tidak dapat berlangsung dalam suasana yang tidak mendukung. Seseorang memperlihatkan sikap mendukung dengan bersikap 1) deskriptif, bukan evaluatif, 2) spontan, bukan strategic, dan 3) provisional, bukan sangat yakin.

Seseorang mengkomunikasikan sikap positif dalam komunikasi interpersonal dengan sedikitnya dua cara: 1) menyatakan sikap positif dan 2) secara positif mendorong orang yang menjadi teman kita berinteraksi. Sikap positif mengacu pada sedikitnya dua aspek dari komunikasi interpersonal. Pertama, komunikasi interpersonal terbina jika seseorang memiliki sikap positif terhadap diri mereka sendiri. Kedua, perasaan positif untuk situasi komunikasi pada umumnya sangat penting untuk interaksi yang efektif. Tidak ada yang lebih menyenangkan daripada berkomunikasi dengan orang yang tidak menikmati interaksi atau tidak bereaksi secara menyenangkan terhadap situasi atau suasana interaksi.

Penggalian riwayat penyakit (anamnesis) dapat dilakukan melalui pertanyaan-pertanyaan terbuka dahulu, yang kemudian diikuti pertanyaan tertutup yang membutuhkan jawaban "ya" atau "tidak". Dokter sebagai seorang yang ahli, akan menggali riwayat kesehatan pasien sesuai kepentingan medis (disease perspective).

Selama proses ini, fasilitasi terus dilakukan agar pasien mengungkapkan keluhannya dengan terbuka, serta proses negosiasi saat dokter hendak melakukan komunikasi satu arah maupun rencana tindakan medis. Pertanyaan-pertanyaan terbuka yang dapat ditanyakan: Bagaimana pusing tersebut Anda rasakan, dapat diceritakan lebih jauh? Menurut Anda pusing tersebut reda bila Anda melakukan sesuatu, meminum obat tertentu, atau bagaimana menurut Anda? Sedangkan pertanyaan tertutup yang merupakan inti dari anamnesis meliputi: Eksplorasi terhadap riwayat penyakit dahulu, Eksplorasi terhadap riwayat penyakit keluarga, Eksplorasi terhadap riwayat penyakit sekarang.

Setelah sesi sebelumnya dilakukan dengan akurat, maka dokter dapat sampai kepada sesi 
memberikan penjelasan. Tanpa informasi yang akurat di sesi sebelumnya, dokter dapat terjebak ke dalam kecurigaan yang tidak beralasan.

Menurut asumsi peneliti, jaminan atas pelayanan yang diberikan oleh dokter sangat ditentukan oleh performance atau kinerja pelayanan, sehingga diyakini bahwa dokter tersebut mampu memberikan palayanan yang handal, mandiri dan profesional dan berdampak pada kepuasan pelayanan yang diterima. Selain dari performance tersebut jaminan dari suatu pelayanan juga ditentukan dari adanya komitmen organisasi yang kuat yang menganjurkan agar, setiap dokter memberikan pelayanan secara serius dan sungguh-sungguh untuk memuaskan orang yang dilayani. Bentuk jaminan yang lain yaitu jaminan terhadap pegawai yang memiliki perilaku, kepribadian (personality Behaviour) yang baik dalam memberikan pelayanan tentu akan berbeda dengan dokter yang memiliki watak atau karakter yang kurang baik dalam memberikan pelayanan.

Aspek kemampuan pelayanan yang akurat adalah berkaitan dengan responsiveness (dukungan) Dokter di Rumah sakit untuk memberikan pelayanan segera, akurat sejak pertama kali pasien datang, tanpa membuat kesalahan apapun, serta memuaskan pasien sehingga pasien benar-benar yakin dengan kemampuan Dokter karena Dokter terkesan baik, terampil, bertanggung jawab dan selalu menginformasikan tindakan dokter yang akan dilakukan pada pasien, misalnya dengan menjelaskan fungsi tindakan kepada pasien.

Meskipun Dokter cepat tanggap dalam melakukan pelayanan namun tidak semua responden merasa puas dengan hal itu, karena meskipun petugas cepat tanggap namun responden menilai petugas kurang ramah terhadap responden sehingga responden merasa kurang dihargai pada saat melakukan kunjungan. Ketanggapan dokter untuk membantu pasien dan memberikan jasa dengan cepat serta mendengar dan mengatasi keluhan dari pasien dan hal tersebut berhubungan dengan tingkat kepuasan pasien.

Menurut Kotler (2005) dukungan dokter yaitu kemauan dari Dokter dan untuk membantu pasien dan memberikan jasa dengan cepat serta mendengar dan mengatasi keluhan dari pasien dan hal tersebut berhubungan dengan tingkat kepuasan pasien. ${ }^{5}$

Hal tersebut sejalan dengan penelitian Parrasuraman bahwa untuk dunia kesehatan, menuju kepuasan pasien Dokter bersedia mendengarkan keluhan, tidak membiarkan pasien menunggu, serta sebagai Dokter adalah tenaga professional yang seharusnya mudah diakses oleh pasien. Membiarkan pasien menunggu tanpa adanya suatu alasan yang jelas dapat menyebabkan persepsi yang negative dalam kualitas pelayanan. ${ }^{6}$

Menurut asumsi peneliti, sikap (responsiveness) berhubungan dengan kepuasan pasien di Rumah sakit. Sikap Dokter saat bertugas harus terus ditingkatkan karena Dokter kurang cepat dalam melayani permintaan medis dan menanggapi keluhan pasien. Adanya kepuasan yang dirasakan pasien membuat mereka memutuskan untuk tetap menggunakan jasa pelayan di Rumah sakit.

Isu kesetaraan (equity) masih menjadi masalah dalam pelayanan kesehatan. Prinsip kesetaraan secara umum menyatakan bahwa layanan kesehatan harus memenuhi kebutuhan kesehatan individu, sehingga individu yang memiliki kebutuhan lebih besar harus mengakses lebih banyak layanan (ekuitas vertikal), tetapi harus ada akses yang sama untuk kebutuhan yang sama (ekuitas horizontal). dengan kata lain, kebutuhan merupakan faktor penentu keadilan dalam distribusi layanan kesehatan. ${ }^{7}$

Kesetaraan juga berarti keadilan atau keadilan sosial, yaitu konsep etis yang didasarkan pada prinsip keadilan distributive yang juga dihubungkan dengan hak asasi manusia. Kesetaraan dalam kesehatan secara luas didefinisikan sebagai ketiadaan kesenjangan sosial. Untuk keperluan operasionalisasi dan pengukuran, kesetaraan dalam kesehatan dapat didefinisikan sebagai ketiadaan disparitas sistematis dalam kesehatan (atau dalam determinan sosial kesehatan) antara kelompok sosial yang memiliki tingkat keuntungan atau kerugian sosial mendasar yang berbeda - yaitu, berbeda posisi dalam hierarki sosial. Ketidaksetaraan dalam kesehatan secara sistematis menempatkan kelompok-kelompok orang yang secara sosial kurang beruntung (misalnya, karena menjadi miskin, perempuan, dan/ atau anggota kelompok ras, etnis, atau agama yang tercabut haknya) pada kerugian lebih lanjut berkenaan dengan kesehatan mereka; kesehatan sangat penting untuk kesejahteraan dan untuk mengatasi efek lain dari kerugian sosial. ${ }^{8}$

Dalam setiap situasi, barangkali terjadi ketidaksetaraan. Salah seorang mungkin lebih pandai, lebih kaya, lebih tampan atau cantik, atau lebih atletis daripada yang lain. Tidak pernah ada dua orang yang benar-benar setara dalam segala hal. Terlepas dari ketidaksetaraan ini, komunikasi interpersonal akan lebih efektif bila suasananya setara. 
Artinya, harus ada pengakuan secara diamdiam bahwa kedua pihak sama-sama bernilai dan berharga, dan bahwa masing-masing pihak mempunyai sesuatu yang penting untuk disumbangkan

Pelayanan publik yang profesional, artinya pelayanan publik yang dicirikan oleh adanya akuntabilitas dan responsibilitas dari pemberi layanan yang efektif dalam pencapaian tujuan dan sasaran. Bila jasa/layanan yang diterima (perceived service) sesuai dengan yang diharapkan, maka kualitas jasa/layanan yang dipersepsikan baik dan memuaskan. Jika jasa yang diterima melampaui harapan pasien, maka kualitas jasa dipersepsikan sebagai kualitas yang ideal. Sebaliknya bila jasa/ layanan yang diterima lebih rendah dari pada diharapkan, maka kualitas/layanan akan dipersepsikan buruk

Dalam Aspek ini dokter diharapkan dapat memberikan jasa secara tepat, kesopansantunan dalam memberi pelayanan, ketrampilan dalam memberikan informasi, kemampuan dalam memberikan keamanan dan kemampuan dalam menanamkan kepercayaan dan keyakinan pasien. Pengetahuan, kesopansantunan, dan kemampuan para dokter di rumah sakit dapat menumbuhkan rasa percaya para pasien. Dokter yang memiliki pengetahuan yang luas sehingga dapat menjawab pertanyaan dari pasien. Kepastian yang mencakup pengetahuan dan keterampilan Dokter. ${ }^{9}$

\section{KESIMPULAN DAN SARAN}

Berdasarkan hasil penelitian dapat disimpulkan bahwa Ada pengaruh keterbukaan (openess) dokter terhadap kepuasan pasien rawat jalan di RSU. Imelda Pekerja Indonesia Medan Tahun 2020. Ada pengaruh Emphaty (empati) dokter terhadap kepuasan pasien rawat jalan di RSU. Imelda Pekerja Indonesia Medan Tahun 2020. Ada pengaruh sikap (supportiveness) dokter terhadap kepuasan pasien rawat jalan di RSU. Imelda Pekerja Indonesia Medan Tahun 2020. Ada pengaruh kesetaraan (equality) dokter terhadap kepuasan pasien rawat jalan di RSU. Imelda
Pekerja Indonesia Medan Tahun 2020. Pada penelitian ini disarankan agar dokter dapat terus meningkatkan kecakapan atau kemampuan berkomunikasi sehingga mampu membuat pasien terbuka, memiliki sikap mendukung, positif dan kesetaraan agar dokter dapat informasi yang diperlukan dan memberikan penanganan yang tepat kepada pasien dan pasien menjadi sembuh

\section{DAFTAR PUSTAKA}

1. Larasati, T. A. Komunikasi DokterPasien Berfokus Pasien pada Pelayanan Kesehatan Primer. Jurnal Kedokteran Universitas Lampung, 3(1), 160-166; 2020

2. Konsil Kedokteran Indonesia; 2012:

3. Rachmania, A., \& Arifin, Z. Klasifikasi Kategori dan Identifikasi Topik Pada Artikel Berita Berbahasa Indonesia. Surabaya: Institut Teknologi Sepuluh Nopember Surabaya, Indonesia; 2011.

4. Grönroos C. Service Management and Marketing: A customer relationship management approach. J. Wiley; 2000

5. Kotler, Philip. 2005. Prinsip-prinsip Pemasaran Jilid I. Jakarta: Erlangga.

6. Joint Comission International. Hospital Patient Safety Goals. 4th Edition.Oarkbrook Terrace-Illinois: Department of Publication Joint Comission Resources ;2011

7. Goddard \& Smith, 2001. eed Management in Intensive Aquaculture.Chapman and Hall. New York.

8. Braveman, P. \& Gruskin, S., 2003. Defining Equity in Health. Epidemiol Community Health, 57, pp.254-58.

9. Arianto. Komunikasi Kesehatan (Komunikasi Antara Dokter dan Pasien). Palu: Universitas Tadulako ; 2015 